\title{
The Development of the Entrepreneurship Ideas through Information and Communication Technology Knowledge
}

\author{
M Solihat ${ }^{1}$, A W Goran ${ }^{2}$ \\ \{manap.solihat@email.unikom.ac.id ${ }^{1}$, agnesgoran@mahasiswa.unikom.ac.id ${ }^{2}$ \} \\ Departemen Ilmu Komunikasi ,UniversitasKomputer Indonesia, Indonesia ${ }^{1}$ \\ Departemen Akuntansi , UniversitasKomputer Indonesia, Indonesia ${ }^{2}$
}

\begin{abstract}
The purpose of this research is to analyze and identify how the application of ICT knowledge can provide benefits to entrepreneurship. The method used in this research was qualitative and descriptive method with an analysis of the existence of information sources. The knowledge of ICT can provide more value for entrepreneurs, because it does not only rely on the creativity, but skills are also needed to become a reliable entrepreneur, then skills in knowledge of ICT is very beneficial, it can provide effectiveness in disseminating information, connecting with customers, and providing more information for developing good ideas.
\end{abstract}

Keywords: Knowledge, Application, Information Technology, ICT, Entrepreneurs

\section{Introduction}

As time goes by, the field of technology is increasingly widespread. We do the activities never separated from the name of technology. As with the world of entrepreneurship, the need for time and cost efficiency makes all entrepreneurs must apply technology knowledge or often referred to as ICT (Information and Communication Technology). ICT consists of two parts that complement each other and have an interest in life, namely information and communication. Information technology is a process, manipulation and using tools to produce information. While communication technology is everything related to the process by which data transmission is sent from one device to another. Information technology can also be interpreted as a combination of computer and telecommunications technology with other technologies such as hardware, software, databases, and network technology. Information technology provides information for users who need it to make a decision [1]. By utilizing information technology in the business field, it will have a big positive impact on the business nets we build. Here are some important benefits of information technology in the business field: 1). The emergence of new business opportunities (E-business), with increasingly advanced technology and information will encourage some people to create opportunities that are very profitable and very profitable business capital. An example of the use of technology and communication advances is Google. Where many google search engines are used to search for things on the internet and google companies will get many benefits. 2). Reducing production and operational costs, advances in technology and information can help companies reduce production costs so that companies will benefit greatly by spending little and reduce operations so that the company can increase the amount of production in each of its production items. 3). Facilitate the process of communication and monitoring of each employee, facilitate the process of communication and monitoring of each employee who works, so employees do not have to bother coming to the meeting room and gathering together, and make 
teleconferences to communicate with each other about some ideas. This makes meetings more practical and can also monitor the performance of employees [4]. Access to information and dissemination of information, publishing news through the internet can be widely distributed quickly compared to using fax or post. We can disseminate information throughout the world and can interact directly through computers [5].

Fast communication, many facilities on the internet prove a lot of the speed of communicating with the intended person, such as e-mail that has been widely used to send and receive documents. Chat or video conferencing also speeds up communication. So, the role of the development of information technology at this time cannot be separated from the business world, because the development of information technology can provide many various advantages and conveniences in carrying out business activities. In addition to providing benefits in the field of business, information technology can also be misused in matters that are not good. Therefore, the user must be used wisely. Informal technology arises because of the increasingly widespread globalization in organizational life, the increasingly intense competition in the business world and the increasing taste of consumers for goods and services offered. Therefore, to anticipate all these things, companies must seek innovations by utilizing the technology knowledge they possess. ICT can be a facilitator and interpreter for entrepreneurs. ICT knowledge greatly influences the business world and has a positive impact on entrepreneurs in building a business. In this era of global business, advances in information technology are unavoidable, such as telephone, computer, facsimile and satellite facilities as well as many other facilities used in various corporate communication facilities. [2]. Information technology can also make it easier for entrepreneurs to get information remotely short and also at a low cost. Therefore, the management in the organization must be observant and also sensitive to technological developments, especially those relating to information, technical equipment, and the process of converting inputs into outputs. Moreover, management must be able to understand the role of information systems in organizations and businesses. An entrepreneur must have a mindset or aspiration to create employment opportunities for people who are unemployed and not to find work; then an entrepreneur must be creative in creating a business so that it can benefit the community [3].

All entrepreneurs are required to meet the applicable technical standards in the wider community. Therefore, an entrepreneur is highly required to have good knowledge of ICT. ICT knowledge gives added value to an entrepreneur because in the business world the use of ICT has become more widespread; this ICT provides many conveniences for entrepreneurs to find information on the progress of their business [4]. Also, with this knowledge, it can expand ideas for business progress that is being undertaken by an entrepreneur. If we want to be an entrepreneur, not only academic value or general knowledge is needed to become a reliable entrepreneur but also skill is needed, one of skill is how we can use the ability of ICT to be implemented in the world of entrepreneurship. If you want to promote a knowledge-based economy, then ICT is one of the useful knowledge for entrepreneurs, because, in addition to developing business, ICT science can also develop the economy of the country [5]. For example, many college students make some of the businesses, even though they are still studying but they still want to find opportunities that they can do, so they have some benefit on business. Most of them look for opportunities through the knowledge or experience they have such as ICT knowledge, technology enables for college students to find information about what is the trend and needed by consumers at this time. Another example is like online shop. Nowadays, there are many college students and even students also have that always call of social media, through social media there are also many who run their businesses such as online shop, through online shop, the products we offer to consumers not only can be seen 
domestically even overseas can also use or buy products offered in the online shop [6]. Many large companies have already used the application, where internal parties, especially in administration. The application can facilitate the work of managers such as database systems classify company data accurately, and for employee attendance [7]. As another example like the CINEMA 21 company, the company already has an application called M-TIX, where consumers do not need to queue again if they want to buy movie tickets. It is also one of the ideas developed by the company through the knowledge of ICT they have, and their marketing team shows that using the internet or applications can help and attract consumers to buy movie tickets easily. All internet is very strategic; what else is related to marketing, this is very important for entrepreneurs because it can provide new insights and strategies that are very effective in marketing company products and also much more economical in terms of economy, and can expand business [8].

According to Ali and Allan shows that Integrated Marketing Communication on internetbased marketing with variables gives a very positive influence [9]. The internet is a process to promote a product that uses internet services [10]. If entrepreneurship is assisted with information and communication technology, it can also help manage the business and facilitate the people involved to get the information needed relating to the selling price and goods to be purchased [11]. Those who start a business with technology-based, must have a some of supporters including having a strong desire to pursue achievement, conceptual ability, and high problem-solving power, have broad insight and way of thinking, high confidence, tolerance, risk-taking, realistic, and have interpersonal skills, and can control emotions. Basically the knowledge of ICT is not only about making applications and marketing products so that it raises ideas that can develop business, but also in the bookkeeping at the end of each period there will always be accounting calculations, nowadays accounting calculations, especially in large companies use applications such as MYOB, access, and excel. The ICT also requires the expert ability of an accountant who has ICT knowledge because it can facilitate accountants in doing their work. From various references that have been analyzed to make this paper, there are still difficulties in finding references by the title of this paper, but with the existing reference sources, it can still be analyzed to make this paper. The purpose of this research is to analyze and identify how the application of ICT knowledge can provide benefits to entrepreneurship, ICT knowledge that is owned can develop more interesting ideas and innovations for a business that we do.

\section{Method}

Descriptive Research Steps were:

Formulation of the problem, namely the submission of research questions whose answers must be sought using data from the field. In descriptive research, researchers could determine the status of variables or study the relationship between variables. Determine the type of information needed. In this case, the researcher needed to determine what information was needed to answer the questions or problems that have been formulated. It is quantitative or qualitative information. Quantitative information relating to data or information in the form of numbers/numbers such as determine data collection procedures. There are two elements of research that are needed, namely the instrument or tool for collecting data and data sources or samples. That is where the information should be obtained. In research there are several data collection tools including tests, interviews, observations, questionnaires, sociometry. These tools are commonly used in descriptive research. To determine the information processing procedures or data, data and information that has been obtained with selected instruments and 
certain data sources or samples are still rough information or data. Information and data need to be processed so it can be used as material to answer research questions. Draw research conclusions, based on the results of processing the data above, the researcher concludes the results of the descriptive research by answering the research questions and synthesizing all of the answers in one conclusion which summarizes the overall research problems.

\section{Results and Discussion}

Through ICT knowledge, entrepreneurs can develop their business and can compete with other entrepreneurs because this information and communication technology knowledge is something that can be used in this increasingly advanced world or that always call globalization. Appropriate technology development can develop businesses that are based on an entrepreneurial spirit that can optimize the process as well as the results of the business units it develops (Harjono et al., 2013:27). Furthermore, technology also guarantees that it can become a business object that can function as needed, get target customers, and can sell products to gain profits and provide economic impact and benefits. For example, there are several companies using ICT knowledge to develop their companies such as creating applications. Application creation is necessary to have extensive ICT knowledge in order to create an application that is useful for the company. The application is a program created to facilitate entrepreneurs in doing their business. Here will be presented some photos of the application and the main menu program that is made and also used in several companies (Figure 1). 


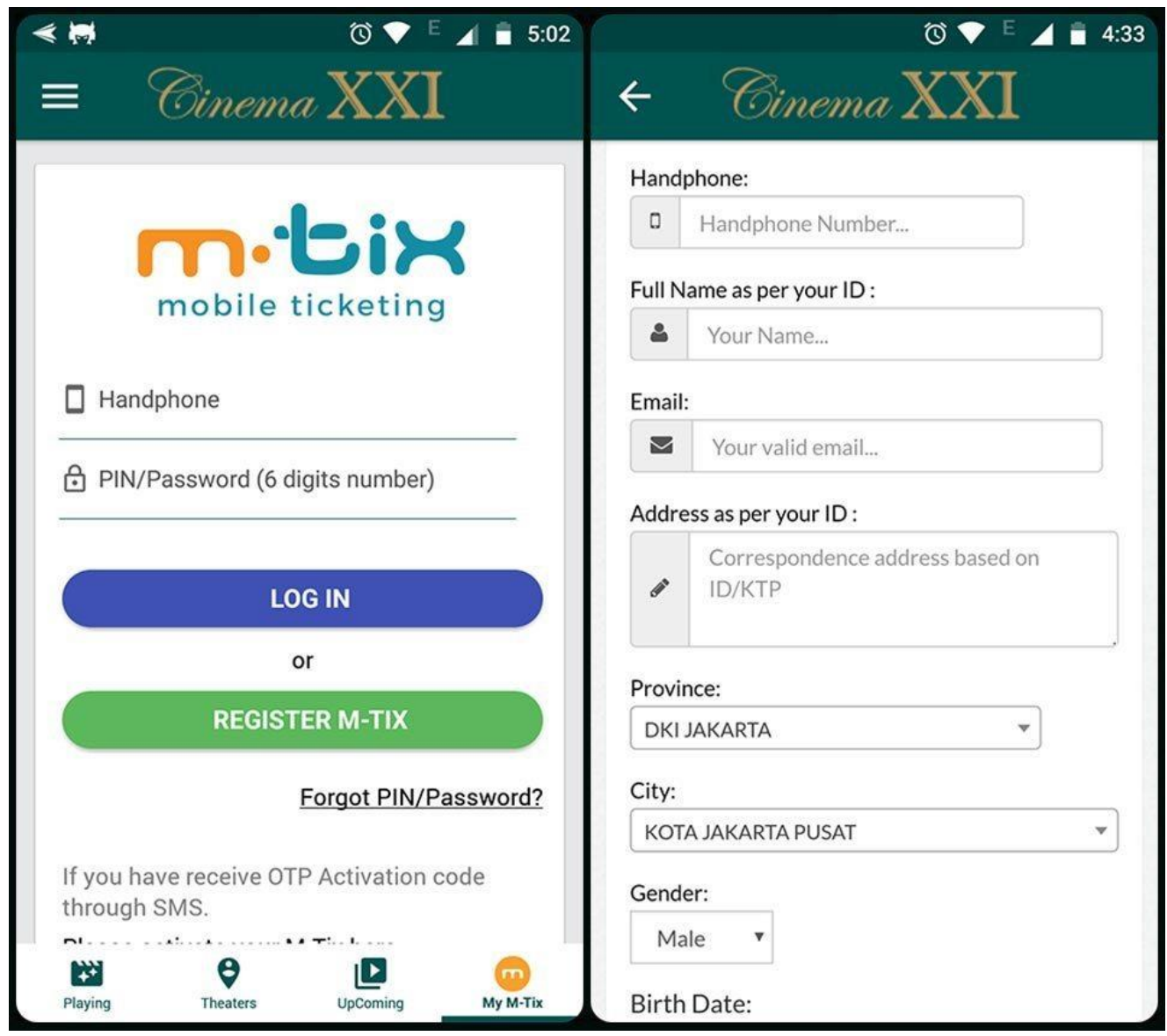

Fig 1. Ticketing Order M.TIX

In Figure 1, this M-TIX is an application of the Cinema XXI company, and its function is to make movie ticket orders, this is very easy for consumers to buy tickets without having to queue long at the counter. This information system is used not only to make it easier for consumers but also to make it easier for workers who work in the counter beside it can attract consumers (Figure 2). 


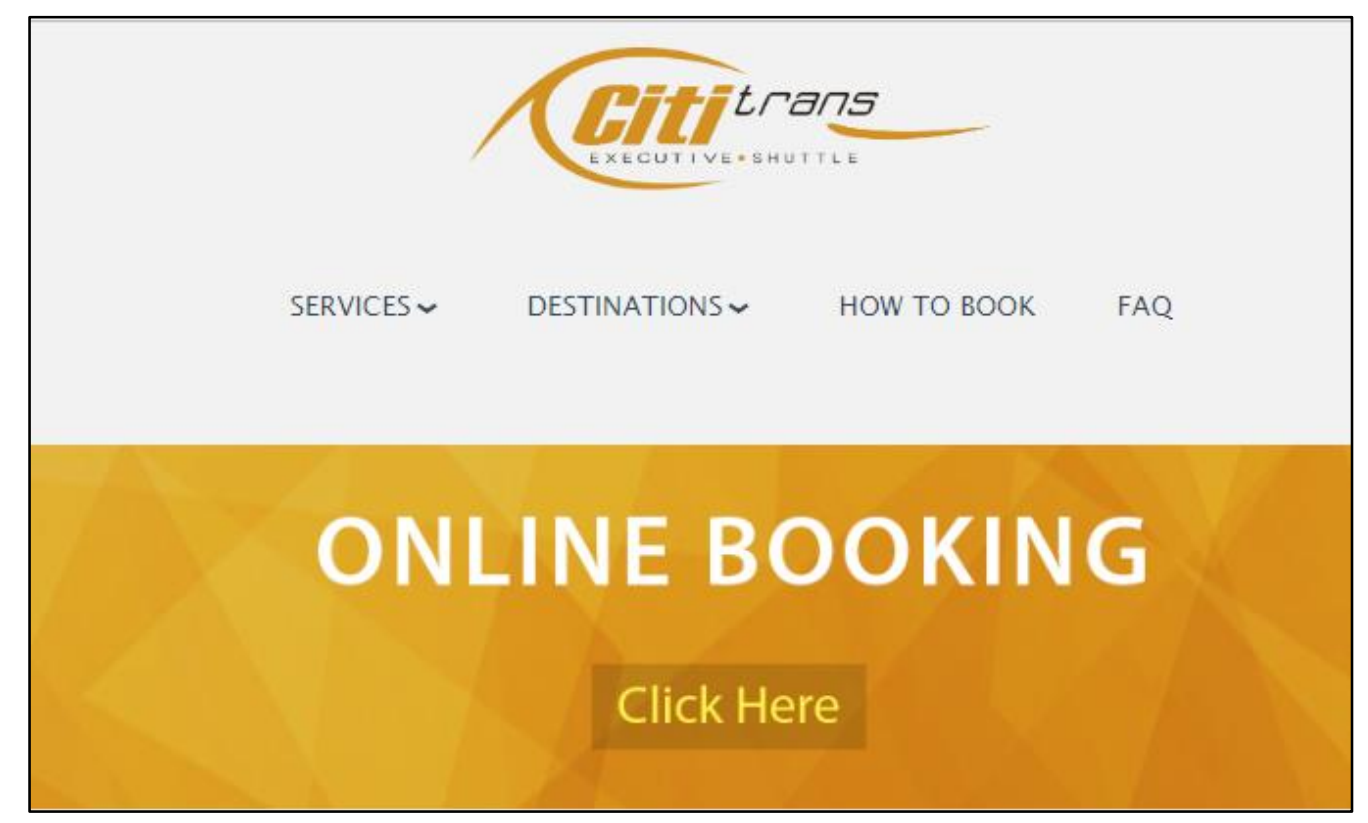

Fig 2. CitiTrans.

Citi Trans information system function is almost the same as M-TIX, which distinguishes it is the M-TIX application is a movie ticket, but Citi Trans is a travel ticket. On this application consumer can order their travel ticket, they can choose their date, day and destination by using this application, without having to go to the place to buy a ticket (Figure 3). 


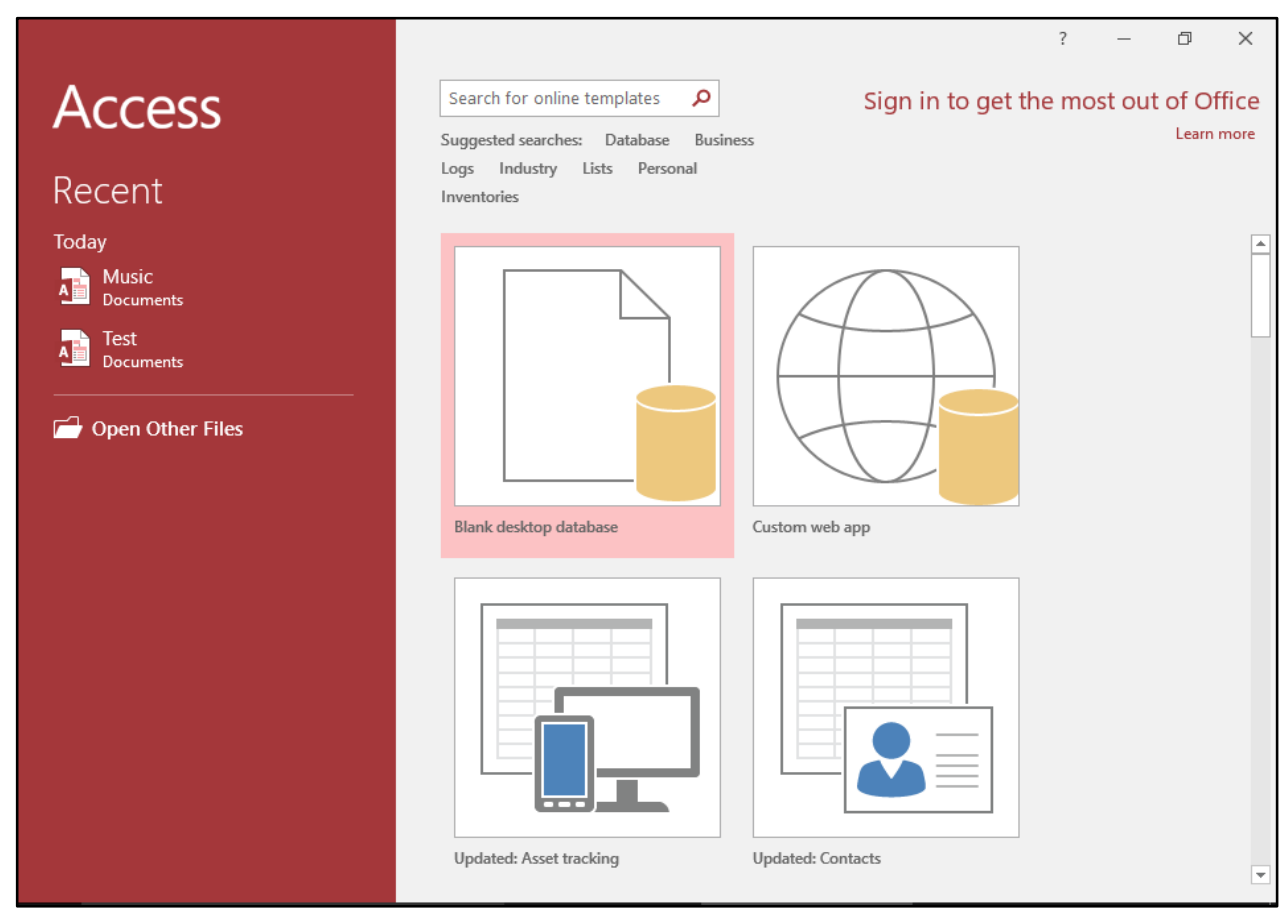

Fig 3. Access.

It is widely known that to build a business; there will be an inventory because that entrepreneurship must also be able to manage inventories technologically because an entrepreneur will make inventory purchases and employee data while running the business. Therefore, this access program can be very helpful in managing inventory and existing data. (Figure 4). 


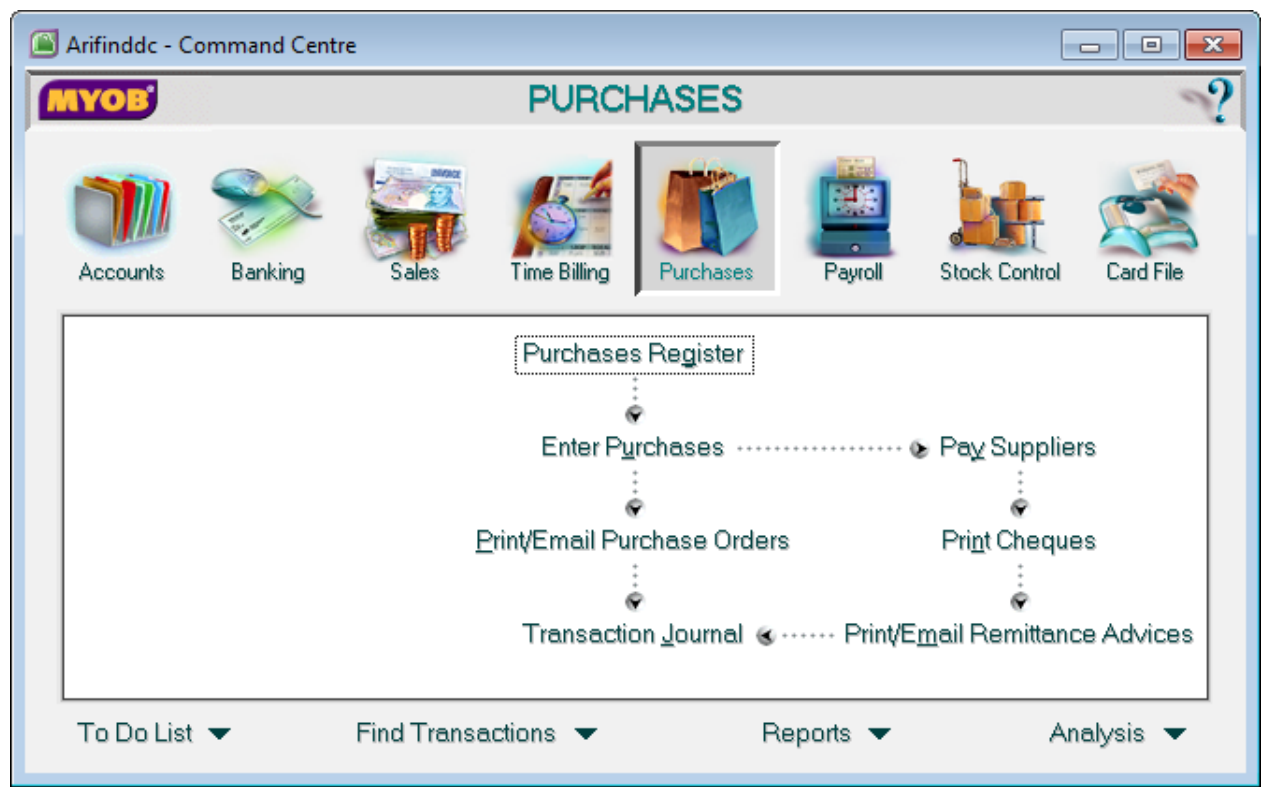

Fig 4. MYOB.

MYOB is a user-friendly program and has the potential to customize according to company needs. In the future, more comprehensive development and breakthroughs are expected as reliable ERPs. MYOB support is very helpful, every time something is not understood, or there are problems in implementation, the MYOB team responds quickly to provide a solution. The Enterprise version is designed specifically for manufacturing companies, which will help you process raw materials, semi-finished, and finished goods. This software can also be applied in business services such as restaurants, workshops, salons \& spas, to educational institutions and courses. with the "project and department" module, it can calculate the estimated project costs to profit per project. Also, Management of stock items with the FIFO / Average Method, MultiUnit, Multi warehouse, to the Most Selling Goods Report. It is equipped with maturity debts remainder.

\section{Conclusion}

Technological developments are increasingly widespread, so competitiveness will also be higher, so all our activities cannot be separated from the name of technology. Therefore, ICT knowledge is very helpful for entrepreneurs to develop and be able to compete with other entrepreneurs. With the knowledge of ICT, entrepreneurs can access information easily, and can also find market targets that can help entrepreneurs to advance their businesses. ICT knowledge is very useful for entrepreneurs because through this knowledge it will help entrepreneurs to develop their ideas in doing business, and can also provide innovations in business. Moreover, technology can also help entrepreneurs to connect with their customers, for example, such as an online shop. Online shop business always deals directly with its customers by chatting on cell phones. Therefore, technology is beneficial for an entrepreneur 


\section{References}

[1] Zeghal, D., \& Maaloul, A.: Analysing value added as an indicator of intellectual capital and its consequences on company performance. Journal of Intellectual capital, 11(1), 3960. (2010)

[2] Febriani, V. W., Wijaya, N. A., \& Sanjaya, R.: High School Technopreneurship Program to Increase the Educational Games for Students. Int. J. Comput. Internet Manag, 1, 25-1. (2014)

[3] Oosterbeek, H., Van Praag, M., \& Ijsselstein, A.: The impact of entrepreneurship education on entrepreneurship skills and motivation. European economic review, 54(3), 442-454. (2010)

[4] Kuratko, D. F., Hornsby, J. S., \& Covin, J. G.: Diagnosing a firm's internal environment for corporate entrepreneurship. Business Horizons, 57(1), 37-47. (2014)

[5] McQuaid, R. W.: Entrepreneurship and ICT industries: support from regional and local policies. Regional Studies, 36(8), 909-919. (2002)

[6] Li, H., \& Kannan, P. K.: Attributing conversions in a multichannel online marketing environment: An empirical model and a field experiment. Journal of Marketing Research, 51(1), 40-56. (2014)

[7] Nah, F. F. H., Siau, K., \& Sheng, H.: The value of mobile applications: a utility company study. Communications of the ACM, 48(2), 85-90. (2005)

[8] Mathews S, Bianchi C, Perks K J, Healy M, \& Wickramasekera R.: Internet marketing capabilities and international market growth. International Business Review, 25(4) pp.820-830 (2016)

[9] Aswani R, Kar A K, Ilavarasan P V, \& Dwivedi Y K.: Search engine marketing is not all gold: insights from Twitter and SEOClerks. International Journal of Information Management, 38(1) pp.107-116 (2018)

[10] Mittal A, \& Mohan D.: Growth of Internet Marketing: The Indian Scenario. MANTHAN: Journal of Commerce and Management, 3(2) pp.108-120 (2016)

[11] Raharjo, S., Matsumoto, T., Ihsan, T., Rachman, I., \& Gustin, L.: Community-based solid waste bank program for municipal solid waste management improvement in Indonesia: a case study of Padang city. Journal of Material Cycles and Waste Management, 19(1), 201-212. (2017) 